\title{
Release kinetics of cardiac biomarkers in patients undergoing valve replacement surgery for rheumatic heart disease
}

\author{
SK Agarwal ${ }^{\text {* }}$, S Singh ${ }^{2}$, A Kapoor ${ }^{2}$, S Pandey ${ }^{1}$, A Sinha² S Kumar $^{2}$, H Rai ${ }^{2}$, S Tewari ${ }^{2}$, N Garg ${ }^{2}$, PK Goel ${ }^{2}$ \\ From 23rd World Congress of the World Society of Cardio-Thoracic Surgeons \\ Split, Croatia. 12-15 September 2013
}

\section{Background}

Levels of brain natriuretic peptide (BNP) increase following $C A B G$ and predict post-operative outcomes. Release kinetics of BNP, Troponin-I (TnI) and CKMB after valve replacement are not well characterized.

\section{Methods}

We assessed levels of these biomarkers 24 hours prior and 6,24, $48 \mathrm{hrs}, 1$ month following mitral/aortic valve replacement in 50 patients (mean age 36.7 yrs, LVEF $54.4 \%, 80 \%$ males).

\section{Results}

Mean baseline BNP, TnI and CK-MB levels were 304.01 $\mathrm{pg} / \mathrm{ml}, 0.03 \mathrm{ng} / \mathrm{ml}$ and $0.99 \mathrm{ng} / \mathrm{ml}$. BNP initially decreased within 6 hours of surgery, and peaked at 24 hours; TnI and CKMB showed an early rise, with declining trends by $24 \mathrm{hrs}$. Peak BNP levels occurred in $90 \%$ patients by 24-48 hrs, while for TnI and CKMB this occurred in only 15-30\%. Mean delta (peak-baseline) BNP, TnI, CKMB was $660.1 \mathrm{pg} / \mathrm{ml}, 8.1 \mathrm{ng} / \mathrm{ml}$ and $32.3 \mathrm{ng} / \mathrm{ml}$. At 1 month, levels of all biomarkers were not significantly different from baseline. Patients with higher baseline BNP more commonly had atrial fibrillation (71vs $33 \%, \mathrm{p}=.02$ ), higher right ventricular systolic pressure $(69.7 \mathrm{vs} 43.9 \mathrm{~mm} \mathrm{Hg}$, $\mathrm{p}<0.001)$, higher Euroscore II $(2.42 \mathrm{vs} 1.49, \mathrm{p}=0.006)$, longer inotrope duration ( $56.1 \mathrm{vs} 26.5 \mathrm{hrs}, \mathrm{p}=0.03)$, ventilator support time (35.6vs21.7 hrs, $\mathrm{p}=0.04)$, longer ICU (4.8vs3.2 days, $\mathrm{p}=0.02)$ and hospital stay (6.8vs5.2 days, $\mathrm{p}=0.03)$. Inotrope duration $>42 \mathrm{hrs}$, ventilation time $>29 \mathrm{hrs}$ and
ICU stay>4 days was seen in $42 \%$ vs $19 \%, 30 \%$ vs $9 \%$ and $33 \%$ vs $14 \%$ respectively in patients with baseline $\mathrm{BNP}>/<200 \mathrm{pg} / \mathrm{ml}$. Only baseline BNP was a significant predictor of inotrope duration $(\mathrm{p}=0.01)$ and ventilation time ( $\mathrm{p}=0.02)$. Only 24 hour post-operative BNP and delta BNP were predictors of inotrope duration $>42 \mathrm{hrs}$, ventilation time $>29 \mathrm{hrs}$ and ICU stay $>4$ days.

\section{Conclusion}

Release kinetics of cardiac biomarkers following valve surgery are significantly different from each other. Of all the biomarkers, only BNP levels had an association with post-operative inotrope duration, ventilation time and ICU stay in patients undergoing valve replacement.

\section{Authors' details}

${ }^{1}$ Cardio-Thoracic Surgery, Sanjay Gandhi PGIMS, Lucknow, India. ${ }^{2}$ Cardiology, Sanjay Gandhi PGIMS, Lucknow, India.

Published: 11 September 2013

\footnotetext{
doi:10.1186/1749-8090-8-S1-P145

Cite this article as: Agarwal et al:: Release kinetics of cardiac biomarkers in patients undergoing valve replacement surgery for rheumatic heart disease. Journal of Cardiothoracic Surgery 2013 8(Suppl 1):P145.
} 